\title{
Antioxidant Vitamins and Trace Elements Status of Diabetics in Sokoto, Nigeria
}

\author{
${ }^{1}$ U. Wali, ${ }^{1}$ M.U Jogana, ${ }^{1}$ A.L Zarummai and ${ }^{2}$ Y. Saidu \\ ${ }^{1}$ Dept. of Chemical Pathology, School of Medical laboratory Science, College of Health Sciences. \\ ${ }^{2}$ Dept. of Biochemistry, Usmanu Danfodiyo University, Sokoto \\ [Corresponding Author: E-mail: usmanwali90@yahoo.com]
}

\begin{abstract}
Diabetes mellitus is associated with elevated oxidative stress via increased generation of reactive oxygen species (ROS), and decline in antioxidant defences. Increased oxidative stress is thought to play a role in the development of diabetic complications. In the current study, vitamins $\mathrm{A}, \mathrm{C}$, and $\mathrm{E}$, chromium, manganese and zinc levels were estimated in 54 diabetics attending the outpatient clinic of the Usmanu Danfodiyo University Teaching Hospital, Sokoto, Nigeria and the results compared with those of apparently healthy non-diabetic volunteers of comparable age and social status. Serum levels of vitamin $\mathrm{A}, \mathrm{C}$, and $\mathrm{E}$ were $23.0 \pm 6.5 \mu \mathrm{g} / \mathrm{dl}, 15.1 \pm 8.3 \mu \mathrm{mol} / 1,7.3 \pm 4.0 \mu \mathrm{mol} / \mathrm{l}$ and $51.7 \pm 14.1 \mu \mathrm{g} / \mathrm{dl}, 42.1 \pm 20.3$ $\mu \mathrm{mol} / 1$ and $30.5 \pm 8.4 \mu \mathrm{mol} / 1$ in diabetics and non - diabetic subjects respectively. There was significantly $(\mathrm{P}<0.05)$ decreased levels of antioxidant vitamins in diabetics. The serum levels of $\mathrm{Cr}(2.6 \pm$ $1.2 \mathrm{mg} / \mathrm{l}), \mathrm{Mn}(8.2 \pm 2.8 \mathrm{mg} / \mathrm{l})$ and $\mathrm{Zn}(9.4 \pm 6.9 \mathrm{mg} / \mathrm{l})$ were significantly $(\mathrm{P}<0.05)$ low in diabetics. Most $(82 \%)$ of the diabetics have deficient serum levels of the vitamins and minerals. The results suggest that diabetics in the study area have low serum levels of antioxidant vitamins and trace elements, an indication that the diabetics are predisposed to increased oxidative onslaught.

Keywords: Diabetes mellitus, Serum vitamins A, C, and E, Chromium, Manganese, and Zinc.
\end{abstract}

\section{INTRODUCTION}

Diabetes mellitus is a chronic metabolic disorder affecting carbohydrate, lipid and protein metabolism. It is a heterogenous group of disorder characterized by hyperglycaemia due to impaired glucose utilization, resulting from defects in insulin secretion, insulin action, or both (Reaven, 1988). It is one of the worldô greatest health problems. The current estimate shows that more than 285 million people worldwide are affected by the disease representing $6.4 \%$ of the world population (Shaw et al., 2010). It has been predicted that the world-wide estimate of diabetes will reach $7.7 \%$ by the year 2030 (Shaw et al., 2010). Nigerian diabetic population is put at 3.9\% as at 2010 (Shaw et al., 2010). Diabetics are predisposed to micro and macrovascular complications that result in significant morbidity and mortality (WHO 1994; Edemeka et al., 1999). They are characterized by low plasma level of both enzymatic and non-enzymatic antioxidant defences, which make their cells prone to oxidative attack (Martin et al., 2003).

Epidemiological evidence suggests that serum vitamin $\mathrm{A}, \mathrm{C}$ and $\mathrm{E}$, chromium, manganese and zinc, are potent antioxidants and may play a protective role in the development of chronic diseases including diabetes, cancers, cardiovascular diseases, and inflammatory diseases (Coyne, 2005). Multiple factors have been associated with increased oxidative stress in diabetes mellitus. These factors include glucose autoxidation that results in the production of free radicals, an increase in protein glycation and a decrease in antioxidant defences (Bilbis, 2008). Enhanced oxidative stress is considered an underlying condition that is responsible for some of the complications of diabetes (Packer, 2002).

Diabetes mellitus being a degenerative disease, therefore, may be initiated as a result of peroxidation caused by free radicals. Vitamins A, $\mathrm{C}$, and $\mathrm{E}$, chromium, manganese and zinc possess antioxidant properties. Deficiency of these may thus increase susceptibility to the disease. The development of diabetic late complications (Cataract, nephropathy, retinopathy and neuropathy) is associated with an increased presence of free radicals and therefore elevated oxidative stress of the human body (Packer et al., 2000). Thus, diabetic populations are associated with higher rate of kidney disease, blindness, gangrene and coronary heart disease several times more than the non-diabetic populations. It is expected that this study will stimulate interests, 
discussion and further studies on the role of antioxidant vitamins and trace elements vis ï a vis complications of diabetes mellitus.

In this study serum vitamins $\mathrm{A}, \mathrm{C}$ and $\mathrm{E}, \mathrm{Cr}, \mathrm{Mn}$ and $\mathrm{Zn}$ were estimated in diabetics and the results compared with those of apparently healthy nondiabetics of comparable socio-economic status.

\section{MATERIALS AND METHODS}

Subjects: The subjects employed for this study were 54 diabetic patients of both sexes who were attending the medical outpatient clinic of the Usmanu Danfodiyo University Teaching Hospital, Sokoto, Nigeria. Also, 50 apparently healthy subjects of both sexes were recruited to serve as control. The consents of all the subjects were sought for and obtained. Ethical committee approval was also obtained for the research.

Blood Samples: Fasting blood samples were collected by venipuncture and delivered into clean dry tubes and allowed to clot at room temperature. The samples were centrifuged at $3000 \mathrm{rpm}$ for 5 minutes using desktop centrifuge and the serum separated and kept in labelled sample bottles at ($20^{\circ} \mathrm{C}$ ) until required. Serum glucose was estimated within few hours of sample collections.

Reagents: Glucose oxidase assay kit was obtained from Randox laboratories, Switzerland. All other chemicals and reagents were of analytical grade and purchased from Sigma Chemical Company, USA.

Analytical Methods: Serum glucose was estimated using the glucose oxidase method of Trinder (1964). Vitamin A level was determined by method of Bassey et al. (1946), Vitamin C level was determined by method of Roe and Kuether (1943); Vitamin E was determined by method of Neild and Pearson, (1967), Chromium, Manganese and Zinc were estimated using UNICAM 969 Atomic Absorption Spectrophotometer.

Statistical Analysis: Results are presented as mean \pm standard deviation and separated on the basis of gender. Significance differences in mean at 5\% level were determined using ANOVA. Serum levels of antioxidant vitamins and trace elements were correlated with the serum glucose levels of both the diabetic and control subjects and correlation coefficients determined.

\section{RESULTS}

The results of the current work show significant difference $(\mathrm{P}<0.05)$ between serum glucose of the diabetic and non-diabetics. Serum levels of vitamin $\mathrm{A}, \mathrm{C}$, and $\mathrm{E}, \mathrm{Cr}, \mathrm{Mn}$ and Zinc were significantly low $(\mathrm{P}<0.05)$ in diabetics than in the non-diabetic (Table 1). Gender appears not to have significant $(\mathrm{P}>0.05)$ effect on the serum levels of vitamins A, E and $\mathrm{Zn}$. Serum vitamin C, $\mathrm{Cr}$ and $\mathrm{Mn}$ are however affected significantly $(\mathrm{P}<0.05)$ by gender.

Table 1: Serum FBS, Vitamins and Minerals of Diabetics in Sokoto, Nigeria.

\begin{tabular}{|c|c|c|c|c|c|c|}
\hline & \multicolumn{2}{|c|}{ Diabetics } & \multicolumn{3}{|c|}{ Control } & \multirow[b]{2}{*}{ Total } \\
\hline Parameters & Male & Female & Total & Male & Female & \\
\hline $\mathrm{N}$ & 25 & 29 & 54 & 31 & 19 & 50 \\
\hline Age of subjects (Yrs) & $44.2 \pm 8.7$ & $41.7 \pm 6.8$ & $43.0 \pm 7.8$ & $46.1 \pm 10.6$ & $42.7 \pm 9.8$ & $44.4 \pm 10.2$ \\
\hline FBS $(\mathrm{mmol} / \mathrm{l})^{*}$ & $14.2 \pm 3.0^{\mathrm{a}}$ & $12.6 \pm 2.5^{\mathrm{a}}$ & $13.4 \pm 2.8^{\mathrm{a}}$ & $3.7 \pm 0.8$ & $4.0 \pm 1.6$ & $3.9 \pm 1.2$ \\
\hline Vitamin $\mathrm{A}(\mu \mathrm{g} / \mathrm{dl})^{*}$ & $26.2 \pm 6.3^{\mathrm{a}}$ & $19.8 \pm 6.7^{\mathrm{a}}$ & $23.0 \pm 6.5^{\mathrm{a}}$ & $52.2 \pm 16.1$ & $50.1 \pm 12.1$ & $51.7 \pm 14.1$ \\
\hline Vitamin $C(\mu \mathrm{mol} / \mathrm{l})^{*}$ & $17.0 \pm 4.3^{\mathrm{a}}$ & $13.1 \pm 12.3^{\mathrm{a}}$ & $15.1 \pm 8.3^{\mathrm{a}}$ & $31.8 \pm 19.3$ & $41.3 \pm 19.5$ & $36.6 \pm 19.4$ \\
\hline Vitamin $\mathrm{E}(\mu \mathrm{mol} / \mathrm{l}) *$ & $7.4 \pm 4.6^{\mathrm{a}}$ & $7.1 \pm 3.4^{\mathrm{a}}$ & $7.3 \pm 4.0^{\mathrm{a}}$ & $18.1 \pm 7.9$ & $22.2 \pm 8.3$ & $20.2 \pm 8.1$ \\
\hline $\mathrm{Cr}(\mathrm{mg} / \mathrm{l})^{*}$ & $1.4 \pm 0.6^{\mathrm{a}}$ & $1.2 \pm 0.6^{\mathrm{a}}$ & $1.3 \pm 0.6^{\mathrm{a}}$ & $9.4 \pm 1.3$ & $7.2 \pm 2.7$ & $8.3 \pm 2.0$ \\
\hline $\operatorname{Mn}(\mathrm{mg} / \mathrm{l})^{*}$ & $4.8 \pm 1.6^{\mathrm{a}}$ & $3.4 \pm 1.2^{\mathrm{a}}$ & $4.1 \pm 1.4^{\mathrm{a}}$ & $30.9 \pm 15.8$ & $23.1 \pm 10.9$ & $27.0 \pm 13.4$ \\
\hline $\mathrm{Zn}(\mathrm{mg} / \mathrm{l})^{*}$ & $3.5 \pm 1.1^{\mathrm{a}}$ & $5.9 \pm 3.5^{\mathrm{a}}$ & $4.7 \pm 2.3^{\mathrm{a}}$ & $33.9 \pm 16.7$ & $34.8 \pm 9.9$ & $34.4 \pm 13.3$ \\
\hline
\end{tabular}

*Values bearing asterisk differ significantly $(\mathrm{P}<0.05)$ using ANOVA.

Values differ significantly from the respective control. 
Table 2: Prevalence of Antioxidant Vitamins and Trace Elements Deficiencies in Diabetics in Sokoto, Nigeria.

\begin{tabular}{llccc}
\hline & & \multicolumn{3}{c}{ Percentage of subjects with deficiencies } \\
Parameters & Normal Range* & Male & 82.70 & Total** \\
\hline Vitamin A $(\mu \mathrm{g} / \mathrm{dl})$ & 31 ï 53 & 80.00 & 100.00 & 81.35 \\
Vitamin C $(\mu \mathrm{mol} / \mathrm{l})$ & 24 ï 32 & 88.00 & 89.70 & 94.40 \\
Vitamin E $(\mu \mathrm{mol} / \mathrm{l})$ & 14 ï 22 & 84.00 & 70.00 & 87.00 \\
$\mathrm{Cr}(\mathrm{mg} / \mathrm{l})$ & 3.0 ï 8.0 & 60.00 & 100.00 & 65.00 \\
$\mathrm{Mn}(\mathrm{mg} / \mathrm{l})$ & 12.0 ï 15.0 & 100.00 & 100.00 \\
$\mathrm{Zn}(\mathrm{mg} / \mathrm{l})$ & 19.0 ï 25.0 & 95.00 & 100.00 & 97.50 \\
\hline
\end{tabular}

*Serum levels antioxidant vitamins and trace elements for apparently healthy non-diabetic subjects were used for deciding the normal range in the study area.

**Total is pooled values for both the male and female subjects.

Values obtained for the control subjects, who were apparently healthy subjects of comparable social background, economic status and age were used as the reference range (Table 2). The reference range was obtained taking the values between the lowest and highest of the control subjects.

Table 3: indicate significant $(\mathrm{P}<0.05)$ negative correlation coefficients between serum glucose and antioxidant vitamins and trace elements.

Table 3: Correlation Coefficient (r) of Serum Glucose with Serum Antioxidant Vitamins and Trace Elements of Diabetics in Sokoto, Nigeria.

\begin{tabular}{llll}
\hline Independent & \multicolumn{2}{c}{ DIABETICS* } \\
\cline { 2 - 4 } Variable & Male & Female & Total \\
\hline Vitamin A & -0.50 & -0.30 & -0.40 \\
Vitamin C & -0.40 & -0.20 & -0.30 \\
Vitamin E & -0.50 & -0.80 & -0.65 \\
Cr & -0.39 & -0.31 & -0.35 \\
Mn & -0.12 & -0.01 & -0.07 \\
Zn & -3.50 & -0.29 & -1.90 \\
\hline
\end{tabular}

*All the serum antioxidant vitamins, and trace elements are significantly $(\mathrm{P}<0.05)$ negatively correlated with serum glucose levels of the diabetics. Table 3

\section{DISCUSSION}

Diabetes mellitus is characterized by elevated level of oxidative stress indices, decreased levels of antioxidants defences and lipid abnormalities due to lipid peroxidation (Asayama et al., 1993). Antioxidant vitamins and minerals are thought to be effective in increasing the activities of antioxidant defence enzymes, scavenging free radicals, preventing oxidative damage and thereby sparing lipid components of the cells against lipid peroxidation (Zingg et al., 2000). Oxidative stress is suggested to be a potential contributor to the development of diabetes mellitus and the associated complications (Muhammad et al., 2005). This may be connected to the fact that the antioxidant status including antioxidant vitamins and minerals may be inadequate in diabetic subjects. The metabolic significance of the evaluation of antioxidant in diabetics is therefore of paramount importance. In addition to the antioxidant roles, they may act directly on glucose metabolism (Muhammad et al., 2005).

The results of the current study indicate that serum vitamins $\mathrm{A}, \mathrm{C}$ and $\mathrm{E}$ of the diabetic patients, in the study area were significantly $(\mathrm{P}<$ 0.05) lower than the values obtained for the diabetic subjects. The results further reveal no significant difference in levels of vitamins $\mathrm{A}$ and $\mathrm{E}$ between male and female diabetic subjects $(\mathrm{P}>$ $0.05)$, but there was significant difference in vitamin $\mathrm{C}$ level $(\mathrm{P}<0.05)$ between male and female diabetic subjects. This may be due to differences in fat content that exists between male and female (Asayama et al., 1993). Vitamin C acts in aqueous media for its antioxidant actions and is poorly stored in fatty tissues. Most (82\%) of the diabetics showed antioxidant vitamins deficiencies. The implication of this finding cannot be overemphasized. Increased oxidative stress in diabetic patients results in higher utilization of these vitamins and consequently their deficiencies. Thus, increased intake of synthetic or natural antioxidant vitamins could help to reduce or avert diabetic complications 
(Abuhussain and Muhsib 2003). According to Packer (2002) deficiencies of these vitamins have been implicated in the development of diabetic late complications such as nephropathy, cataract, neuropathy, stroke etc. Some studies suggest that people with diabetes have elevated levels of free radicals and lower level of antioxidants (Schneider et al., 2000). Hyperglycaemia generates reactive oxygen species (ROS) and also attenuates antioxidant mechanism, creating a state of oxidative stress (Bilbis, 2008). The B-cells are sensitive to oxidation because their intracellular antioxidant defence mechanisms are weak (Rasilainens et al., 2002).

Diabetic subjects of the study area also show serum chromium deficiency. The serum level of $\mathrm{Cr}$ in the diabetic subjects, in the current work, was significantly $(\mathrm{P}<0.05)$ lower than that of nondiabetic subjects. The results are not affected by sex difference. $\mathrm{Cr}$ is component of glucose tolerance factor which is a soluble and dialyzable organic compound that is required for optimal glucose utilization by the cells (Reaven, 1988). $\mathrm{Cr}$ is also reported to increase insulin binding to cells, number of insulin receptors and activates insulin receptor kinase leading to increase insulin sensitively (Anderson, 2000). Accordingly severe $\mathrm{Cr}$ deficiency was implicated to cause to cause impaired glucose tolerance and subsequent hyperglycemia and glucosuria (Anderson, 2000). $\mathrm{Cr}$ also to raise plasma HDL: LDL ratio (Tuvemo and Gebre-Medhin, 1985).

Serum manganese (Mn) level of diabetic subjects in the current work was lower compared to that of the non diabetic subjects. Mn has been shown to be important in insulin synthesis and secretion (Korc, 1983). It has been shown that type II diabetic subjects respond well to oral doses of $\mathrm{Mn}$ (Rubeenstein et al., 1962). Mn is a cofactor of many enzymes including mitochondrial superoxide dismutase (Murry et al., 1996), manganese activated enzymes play important roles in the metabolism of carbohydrates, amino acids and cholesterol (Nicollof et al., 2004). There are conflicting reports of $\mathrm{Mn}$ deficiency in diabetes mellitus (El-yazigi et al., 1991). Diabetes with higher blood levels of $\mathrm{Mn}$ were reported to be better protected from oxidation of LDL cholesterol (El-yazigi et al., 1991). LDL oxidation contributes to the development of intra-arterial plague, which can lead to heart attack and stroke (Leonhard et al., 1996).

Increased urinary loss of $\mathrm{Zn}$ is a commonly encountered feature of diabetics. High dose of oral zinc might enhance wound healing (Tuvemo and Gebre-Medhin, 1985). A study conducted by Chung et al., (1998) showed that nutrients including vitamin $\mathrm{E}$ and $\mathrm{C}$, Manganese, Chromuim and Zinc all have beneficial effects on the symptoms or complications associated with diabetes. Many of these nutrients appear to be closely associated with insulin metabolism and help maintain proper blood glucose level (Tuvemo and Gebre-Medhin, 1985).

Generally, these antioxidant vitamins and minerals are excreted at higher than normal rates in patients with diabetes mellitus (El-yazigi et al., 1991). This may be connected to be hyperglycaemia mediated polyuria in the patients, consequently, there is a decrease in the plasma levels of the vitamins and minerals in these subjects. This may predispose the subject to further oxidative onslaught and decrease glucose tolerance leading ultimately to the development of late complications of diabetes (Asayama et al., 1993). It may therefore be critical to suggest the inclusion of dietary supplementation of these vitamins and minerals in the management of diabetes mellitus in the study area.

\section{ACKNOWLEDGEMENTS}

The authors acknowledge the assistance of the Usmanu Danfodiyo University and Usmanu Danfodiyo University Teaching Hospital, Sokoto, Nigeria.

\section{REFERENCES}

Abuhussain, A and Muhsib, A (2003). Diabetes and Oxidative Challenge. Vitamins Supplements 95: 58 ï 62.

Anderson, R.A. (2000). Chromium in prevention and control of diabetes. Diabetes Metabol. 26: 22-27.

Asayama, K. Uchida N., Nwakene, T., Hayashibe, H., Dobashi, K., Amemiya, S., Kato, K. and Nakazawa, S. (1993). Antioxidants in Serum of Children with type 1 DM. Free Radical Bio. Med. 15(6): 597-602. 
Wali et al.: Antioxidant Vitamins and Trace Elements Status of Diabetics in Sokoto, Nigeria

Bassey, M. John, U. and Peter, T.N. (1946). Determination of vitamin A. Am. J. Clin. Nutr. 12:210 ï 218.

Bilbis, L.S. (2008). Friends or Foesò Reactive oxygen species in health and disease. Usmanu Danfodiyo University Central University Seminar Series, August $28^{\text {th }}, 2008$ pp. 14.

Chung, T.W., Yu, J.J. and Liu, D.Z. (1998). Apha tocopherol reduces lipid peroxidation stress of erythrocyte membrane in type II diabetes mellitus patients with retinopathy. Diabetes 15: $380-385$.

Coyne, T. (2005). Antioxidant. Am. J. Clin. Nutr 82:3685-3698.

Edemeka, D.B.U, Udomah, M.A. and Onumajuru, A.A. (1999). Acute and chronic complications of type 1 diabetes in Sokoto, Nigeria. Diabetes Inter. 9:70-77.

El-yazigi, A.N., Hannan, J. and Raines, D.A. (1991). Urinary excretion of chromium, copper and manganese in diabetes mellitus associated disorders. Diabetes Resp. 18: 129134.

Korc, M. (1983). Manganese action on pancreatic protein synthesis in normal and diabetic rats. Am. J. Physiol. 254: 628-634.

Leonhardt, W. M. Hanefeld and Muller, (1996). Impact of concentration glycated hemoglobin, Alpha tocopherol, copper and manganese on oxidation of low-density lipoproteins in patients with type 1 diabetes, type II diabetes and control subjects. Clin. Acta 254:173-186.

Martin, A.E. (2003). United Kingdom, $6^{\text {th }}$ edition, Clays publisher Pp192.

Muhammad, A., Mansur, L., Frank, M., Saidu, Y. and Bilbis, S. (2005). Serum antioxidant vitamins levels in non-insulin dependent diabetes mellitus subjects in Sokoto, Nigeria. J. Nig. Soc. Experiment. Bio. 17(2): 107-114.

Murry, R.K., Granner, D.K. Mayes, P.A. and Rodwell, V.W. (1996). Harper's Biochemistry $24^{\text {th }}$ Edition, Prentice ï Hall international, Inc., USA, Pp: 581-598.

Neild, C. and Pearson, S. (1967). Spectrophotometric determination of serum antioxidants. Annal Clin. Biochem.. 42-50.

Nicollof, G.K., Mutaftachiev, V., Strashimiro and Petrova, C. (2004). Serum Manganese in children with diabetes mellitus type 1 . Diabetologia Crotical 3: 47-51.

Packer, L. (2002): Alpha Lipoic acid as a biological antioxidants $J$. Free Radical Bio. Med. 20:1020-1032.

Packer, L.B., Peter I.T., Hans, I.K., George, U. and Philip, B. (2000). Antioxidants and Diabetes Management. Culinary and Hospitality publications, Pp 200 ï 248.

Rasilainens, S., Nieminen, J.M. Levonen, A.L. Otonkoski, T. and Lapatto, R. (2002). Dose dependent cysteine Mediated protection of Insulin-producing cells damage by hydrogen peroxide. Biochem. Pharmacol. 63: 1297 ï 1304.

Reaven, G.M. (1988). Role of Insulin resistance in human disease. Diabetes 37:1595-1607.

Roe, M. and Kuether, J. (1943). Determination of vitamin $C$ In: Varley, $H$. and Alan, $H$. PRACTICAL Clinical Chemistry, $5^{\text {th }}$ edition, Oxford Press, pp. 685-690.

Rubeebstein, A.H., Levin, N.W. and Elliott, G.A. (1962). Mangane induced hypoglycemia. Lancet 2:1348-1351.

Schneider, R.H., Castillo-Richmond, A., Alexander, C.N. (2000). Effects of Stress reduction on Carotid atherosclerosis in hypertensive African-Americans. Stroke 31: 568-573.

Shaw, J.E., Sicree, R.A. and Zimmet, P.Z. (2010). Global estimates of the prevalence of diabetes for 2010 and 2030. Diabetic Res.Clin. Practice. 87: 4 -14.

Trinder, P. (1964). Determination of glucose in blood using glucose oxidase with an alternative oxygen acceptor. Annal Clin. Biochem. 6:24-27.

Tuvemo, T. and Gebre-Medhin, M. (1985). The rule of trace elements in juvenile diabetes mellitus. J Pediat. 12: 213-219.

WHO (1994). WHO study group report on prevention of diabetes mellitus, WHO Geneva 1-92, WHO technical report series No.844.

Zingg, J.M., Ricciarelli, R. and Azzi, A. (2000). Scavenger Receptor and Modified Lipoproteins Fatal Attractions IUBMB life 49: 397-403. 